\title{
The effects of Environmental Enrichment on Some Physiological and Behavioral Parameters of Broiler Chicks
}

\section{-Author(s)}

\section{Yildirim $\mathrm{M}^{\prime}$}

Taskin A'

Department of Animal Science, Agricultural Faculty, Ahi Evran University, Kirsehir 40100, Turkey

\section{nMail Address}

Corresponding author e-mail address Atilla Taskin

Department of Animal Science, Agricultural Faculty, Ahi Evran University, Kirsehir 40100, Turkey

Tel: $\quad$ +903862804800

Email: ataskin@ahievran.edu.tr

\section{EKeywords}

Behavior, broiler, environmental enrichment, tonic immobility.

\section{ABSTRACT}

This study aims to examine the effects of environmental enrichment (EE) practices on some physiological and behavioral parameters of broiler chicks. A total of 280 one-day old Ross 308 mixed-sex broiler chicks with an average initial body weight of $44.5 \pm 0.37 \mathrm{~g}$ were used in a $42-\mathrm{d}$ trial. Broiler chicks were randomly allocated to 20 pens composed of 14 birds in $1 \times 1.4 \mathrm{~m}$ sized floor area. Each of the EE treatment consisted of 5 replicate pens (70 chickens per treatment). The treatments were 1) control; 2) perch for $E E ; 3$ ) ball for $E E$; 4) mirror for $E E$; and 5 ) dust for EE. Final body weights, tonic immobility test results, and rectal temperatures were recorded. Spleen, liver, and bursa fabricius weights were measured. The blood biochemistry of birds was analyzed at the end of the experiment. Besides, gait score test was applied on the $42^{\text {nd }}$ day of experiment. Body weight gain, lymphoid organ weights and rectal temperature values of broilers were not affected by EE treatments on the $21^{\text {st }}$ and $42^{\text {nd }}$ days of the study. At the end of the study, WBC values, tonic immobility values and gait scores of the control groups were found higher than those of the EE groups. HCT and PLT values of the ball groups were found lower than the other groups, concluding that EE improved the welfare of birds.

\section{INTRODUCTION}

Environmental enrichment (EE) is defined as using various objects to improve life quality and normal behavior expression of animals which are kept in cages or in a limited space (Belz et al., 2003). EE is the addition of biologically relevant stimuli to animals' environment to encourage natural behaviors (Leone \& Estevez, 2008). The visuals, audio sounds, structures, plastic materials, and smells are some basic enrichment strategies in poultry housing systems (Adeniji, 2012). EE programs are considered to have an important potential in terms of both farm management and animals' health, productivity, and welfare (Estevez, 2009). Besides, it was reported that these applications decreased fear sensitivity without having any negative effect on birds' growth performance and stress (Altan et al., 2013). However, it should be considered that mirror application can address potential differences in reactive and proactive aggression, although caution should be taken when using the application as some birds are able to self-recognize (Branch et al., 2015). On the other hand, dust bathing is important behavior for chickens that are willing to work for access to litter for both foraging (Widowski \& Duncan, 2000). Fernandes et al. (2015) stated that birds enjoyed red feed particles in pecking behavior. Perches offer birds the possibility to use the third spatial dimension, and can increase movement and exercise while jumping on and off of them as birds move around (Bizeray et al., 2002). 
Fear is a significant indicator of stress for poultry, and Tonic Immobility ( $\mathrm{TI}$ ) is used to determine fear situation for poultry as a reliable criterion (Jones, 1986). When bird is stimulated for $\mathrm{Tl}$, more coward ones stay motionless longer time compared to those which fear less sensitively (Taskin, 2009). Besides, fear negatively affects the welfare level of broilers and accepted as physiological and behavioral reaction when animals perceive any signals such as sudden noise as a danger (Cockrem, 2007).

Environmental enrichments improves immunity in stressed animals (Benaroya-Milshtein et al., 2004; Meijer et al., 2007; Arranz et al., 2010). It is well known that stress factors affect poultry production. When poultry are exposed to stress, the consumption of glucose raises substantially, and liver gives glycogen to blood in order to balance the glucose level in blood (Garrigaet al., 2006). It was determined that cold stress raised glucose level in blood to $205 \mathrm{mg} / \mathrm{dl}$ from 189.8 $\mathrm{mg} / \mathrm{dl}$, raised total protein, cholesterol, triglyceride levels to $3.3 \mathrm{~g} / \mathrm{dl}$ from 3.5, and went down to 110.8 $\mathrm{mg} / \mathrm{dl}$ from 114.8 , to $68.2 \mathrm{mg} / \mathrm{dl}$ from 72.0 in a study conducted about 42-old-day chickens (Daneshyaret al., 2009). Selective breeding in broilers resulted in an increase in performance for many years affecting the welfare of broilers negatively. Fast growing broilers kept under continuous light lose locomotor activity with age due to the significant decrease in time used for this activity. Lower locomotor activity and the increase of growth rate significantly cause gait anomalies and leg problems (Seremet, 2007). It should be taken into consideration that new wood shavings lessen locomotion problems (Almeida Paz et al., 2010). Poor leg health may cause a decline in locomotor activity as well. Perch usage enhances the welfare of laying hens; on the other hand, the effect of perch accessibility on broiler rearing systems remains ambiguous because there is not sufficient research on this subject (Jiao et al., 2014). Therefore, the aim of the current study is to investigate the effects of environmental enrichment tools (perch, ball, mirror, dust) on some physiological (growth, lymphoid organ weights, rectal temperature and blood biochemistry) and behavioral (tonic immobility and gait score) parameters of broiler chicks.

\section{MATERIAL AND METHODS}

This study was conducted with the permission (11.07.2013/1/4) of Ahi Evran University Animal Experiments Local Ethics Committee. In this study, 280 one-day-old Ross ${ }^{\circledR} 308$ broiler chicks both male and female in mixture were used. After all chicks were weighed, they were reared in cages to 4 days of age in a climate-controlled room, and taken to pens in a conventional poultry house with yellow curtains on the $5^{\text {th }}$ day. The broiler chicks were randomly distributed in 20 pens with $1.4 \mathrm{~m}^{2}$ of floor area, at a population density of 10 birds $/ \mathrm{m}^{2}$, and each treatment consisted of 5 pens (70 birds per treatment).

The pens used during experiment were made from wooden material, had a door at the front, and metal wire at all four sides. A $10-\mathrm{cm}$ high wood shaving litter material was bedded on the pen floor. In the first week, the chicks were provided with a temperature of $33^{\circ} \mathrm{C}$, the temperature was then reduced by $3^{\circ} \mathrm{C}$ every week and a temperature of $18^{\circ} \mathrm{C}$ was attained at the end of the sixth week. The experiment was carried out in April and May, in 2015. Traditional fluorescent light (23:1) was applied in the cages used in the experiment. Feed and water were provided ad libitum. The chicks were fed with same commercial broiler starter (230 g CP and $3.100 \mathrm{kcal}$ of ME per $\mathrm{kg}$ ) from 1-d until 21-d and grower (200 g CP and $3.100 \mathrm{kcal}$ of ME per $\mathrm{kg}$ ) from 22-d until the end of the experimental period. Nutrients and energy concentrations of experimental diets met or exceeded the minimum requirements of NRC (1994). Strict sanitation practices were applied throughout the experiment. No bird was sacrificed during the study.

Environmental enrichment consisted of objects designed to encourage pecking and locomotor activity in the pen. The design of the objects was modified based on the results of the previous studies on broiler chickens. The treatments included control, perch for $\mathrm{EE}$, ball for EE; mirror for EE; and dust bath for EE (Fig. 1).

Enrichments objects (mirrors and balls) were suspended from overhead wires in such a way that they dangled from the pen ceiling (Jones et al., 2000). Objects at $30 \mathrm{~cm}$ from the ground were suspended by $5 \mathrm{~cm}$ upgrade in each week at the end of the $42^{\text {th }}$ day. The properties of objects were as follows:

A double-faced mirror $(20 \times 10 \mathrm{~cm})$. The ball was a red one, made of plastic with a diameter of $10 \mathrm{~cm}$. The perch was $120 \mathrm{~cm}$ long with a wooden structure which included a horizontal and a sloped $\left(13^{\circ}\right)$ section. The dust bathing pool was $10 \mathrm{~cm}$ deep, 40-cm diameter plastic black container. There was a small grain of sand in it.

Chicks were weighed weekly and their body weights were taken. The increase of weekly body weight was calculated as subtracting weighing week before the weighing applied. Rectal temperatures 


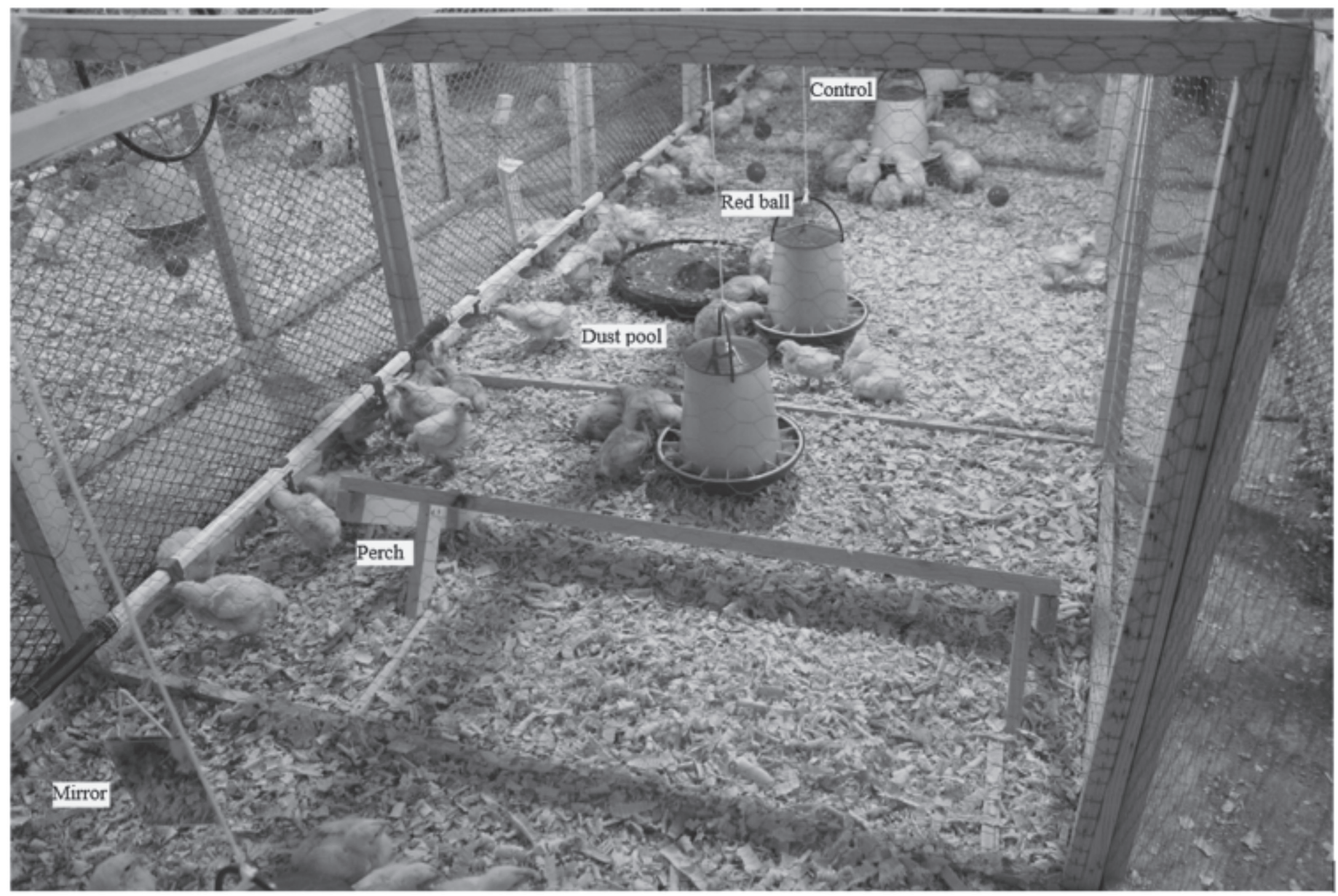

Figure 1 - Enriched pens with perches, dust pools, mirrors and red balls

of the fifteen birds from each group were measured at $06: 00 \mathrm{~h}, 14: 00$, and 18:00 $\mathrm{h}$ of the $21^{\text {st }}$ and the $42^{\text {nd }}$ day by one observer because these hours refer to daily climate changes during the day (Sinkalu et al., 2015). For this purpose, a digital clinical thermometer (Hartmann, Paul Hartman AG, Heidenheim, Germany), was inserted approximately $2 \mathrm{~cm}$ for the $21^{\text {st }}$ day and $5 \mathrm{~cm}$ for the $42^{\text {nd }}$ day into the cloaca and in direct contact with the mucosal wall. The value was recorded after the thermometer gave an alarm sound, indicating that the reading had been stabilized (Sinkalu et al., 2015). At the end of the experiment, 15 birds in each group were slaughtered humanly to get lymphoid organ (spleen, liver and bursa fabricius) weights

The tonic immobility (TI) test was applied as Jones \& Faure (1980) reported. Animals whose TI time was longer were evaluated as more passive, referring to fear while those with shorter TI period were evaluated as being more active and fearless. The TI test of birds was conducted in a separate room within the same building on the $21^{\text {st }}$ and $42^{\text {nd }}$ days. TI induced as soon as the chickens were carried to the test room by restraining them on their right side and wings for 15 seconds (s). The observer was $1 \mathrm{~m}$ away from the test table and waited without noise. A chronometer was used to record latencies until the chicken stood up itself (Taskin, 2009). If the chicken righted itself in $<10$ $s$, it was recaptured and the procedure was repeated. If TI was not induced after 3 trials, the TI duration was recorded as zero. The maximum duration of $\mathrm{Tl}$ allowed was $600 \mathrm{~s}$ (Benoff \& Siegel, 1976). 25 chicks were used for each treatment on the $42^{\text {nd }}$ day $(06: 00 \mathrm{~h}, 14: 00$, and 18:00 h) in our experiment.

The evaluation was based on a gait scoring system developed by Kestin et al. (1992). The conducted test is as follows: The chickens were induced to walk for a distance of $1 \mathrm{~m}$ on a flat surface containing wood shavings, simulating the broiler litter conditions found in the broiler house. The methodology consisted of subjective observations that allowed attributing a score on how the bird walked (Alves et al., 2016b). According to this scoring, gait characteristics were regulated as 0 was normal, and as 5 was the worst.

Blood samples ( $3 \mathrm{ml}$ per bird) were taken from the wing venations of 15 chicks having equal body weight from each group on the $42^{\text {nd }}$ day of the experiment 
and centrifuged for 6 minutes at 3000 speed, and separated into serums (Arctander, 1988). Separated samples were kept at $-80^{\circ} \mathrm{C}$ for glucose, triglyceride, cholesterol, and total protein analyses. After that these analyses were applied with clinical chemistry analyzer (BS-400 Mindray, China). Besides, cell numbers and ratios in blood were determined as analyzing hematological analysis from obtained samples at auto hematology analyzer (BC-5380 Mindray, China). However, stress hormones such as corticosterone and cortisol were not analyzed.

This study was planned on a randomized design. The statistical analyses were performed using the SPSS 16.0 (SPSS Inc., Chicago, IL, USA) software package (2007). The results were expressed as means \pm S.E.M. Significant differences were determined using protected Tukey test $(\mathrm{P} \leq 0.05)$ after ANOVA.

\section{RESULTS AND DISCUSSION}

Body weight values were found as $716.10 \mathrm{~g}$, and $2,573.12 \mathrm{~g}$ on the $21^{\text {st }}$, and $42^{\text {nd }}$ day in control groups, respectively (Fig. 2). Final body weight of control groups was higher compared to other groups without statistical significance. Spleen, liver, and bursa fabricius weights of the control groups were found as $0.67 \mathrm{~g}$, $21.26 \mathrm{~g}$ and $1.53 \mathrm{~g}$ with $2.87 \mathrm{~g}, 59.13 \mathrm{~g}$ and $3.87 \mathrm{~g}$ respectively, on the $21^{\text {st }}$ and $42^{\text {nd }}$ days without statistical significance compared to the EE treatments (Table 1). Rectal temperature values of the control groups were found as $40.95^{\circ} \mathrm{C}$ and $40.75^{\circ} \mathrm{C}$ respectively, in the third and sixth weeks without statistical significance compared to the EE treatments (Fig. 3).

According to $\mathrm{TI}$ responses for the $21^{\text {st }}$ day of trial, $\mathrm{TI}$ induction trial attempts number of the perch groups (2.12) was found higher than that of the other groups (Fig. 4). While ball groups' TI duration (Fig. 5) was found as $165.62 \mathrm{~s}$ which was higher than control groups, dust groups' duration was found lower (100.50s) than that of the control groups $(p<0.05)$. According to $\mathrm{TI}$ responses on the $42^{\text {nd }}$ day, induction trial attempts for $\mathrm{TI}$ of the control groups (2) was found higher than the

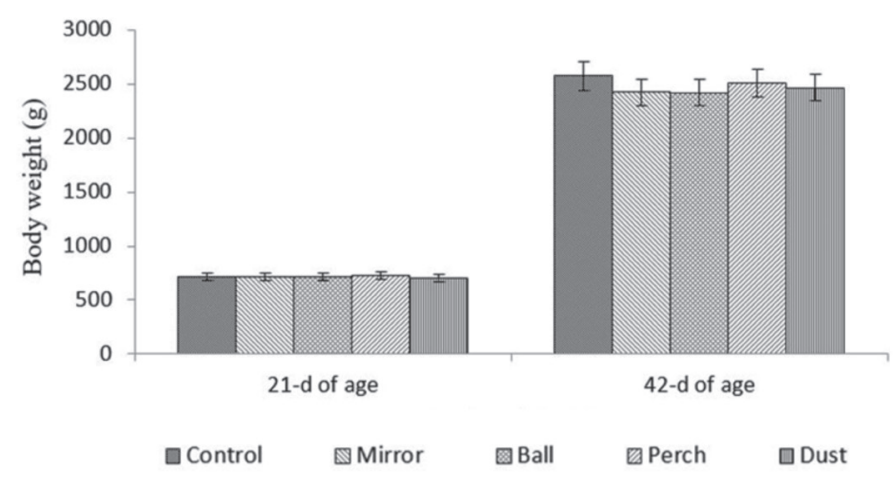

Figure 2 - Body weight (g) in 21-d and 42-d of age.

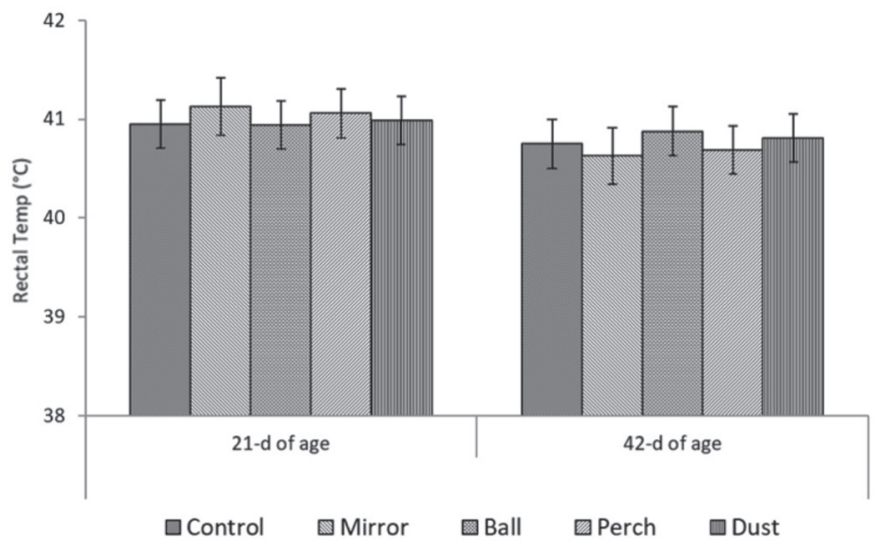

Figure 3 - Rectal temperature $\left({ }^{\circ} \mathrm{C}\right)$ in $21-\mathrm{d}$ and $42-\mathrm{d}$ of age.

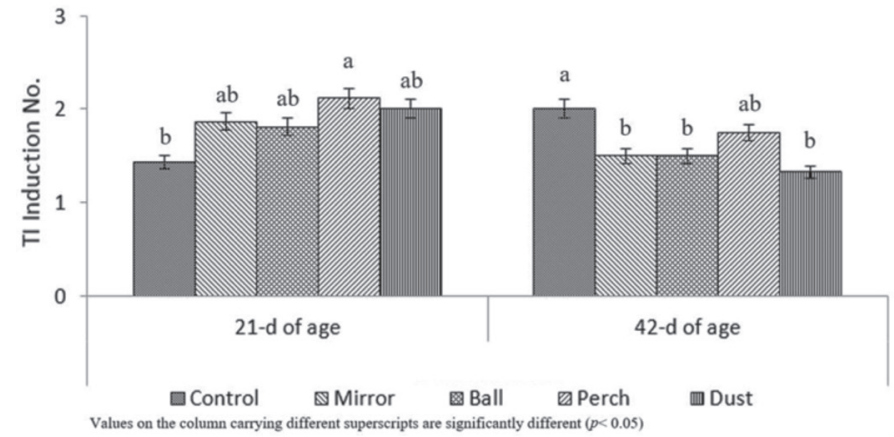

Figure 4 - Tl induction number in 21-d and 42-d of age.

other groups. Duration of the dust groups was found lower than the other groups for the $21^{\text {st }}$ and $42^{\text {nd }}$ days. Duration of the mirror groups was higher than the other groups for the $42^{\text {nd }}$ day $(p<0.05)$.

Table 1 - Weight of spleen, liver and bursa fabricus (g) in 21-d and 42-d of age.

\begin{tabular}{|c|c|c|c|c|c|c|}
\hline \multirow[t]{2}{*}{ Treatments } & \multicolumn{2}{|c|}{ Spleen $(\mathrm{g})$} & \multicolumn{2}{|c|}{ Liver (g) } & \multicolumn{2}{|c|}{ Bursa fabricus (g) } \\
\hline & $21-d$ of age & $42-d$ of age & $21-d$ of age & $42-d$ of age & 21-d of age & $42-d$ of age \\
\hline Control & $0.67 \pm 0.28$ & $2.87 \pm 0.46$ & $21.26 \pm 3.65$ & $59.13 \pm 10.49$ & $1.53 \pm 0.56$ & $3.87 \pm 1.11$ \\
\hline Mirror & $0.64 \pm 0.16$ & $2.81 \pm 0.43$ & $22.24 \pm 2.76$ & $62.42 \pm 12.73$ & $1.41 \pm 0.34$ & $3.89 \pm 1.29$ \\
\hline Ball & $0.61 \pm 0.22$ & $2.98 \pm 0.56$ & $21.70 \pm 2.53$ & $59.61 \pm 11.84$ & $1.35 \pm 0.60$ & $3.90 \pm 0.91$ \\
\hline Perch & $0.61 \pm 0.16$ & $2.54 \pm 0.22$ & $21.14 \pm 2.02$ & $59.75 \pm 11.46$ & $1.35 \pm 0.39$ & $4.04 \pm 1.75$ \\
\hline Dust & $0.81 \pm 0.32$ & $2.88 \pm 0.45$ & $21.42 \pm 2.80$ & $64.77 \pm 12.45$ & $1.70 \pm 0.57$ & $3.78 \pm 1.28$ \\
\hline
\end{tabular}

All values are means \pm SEM. 


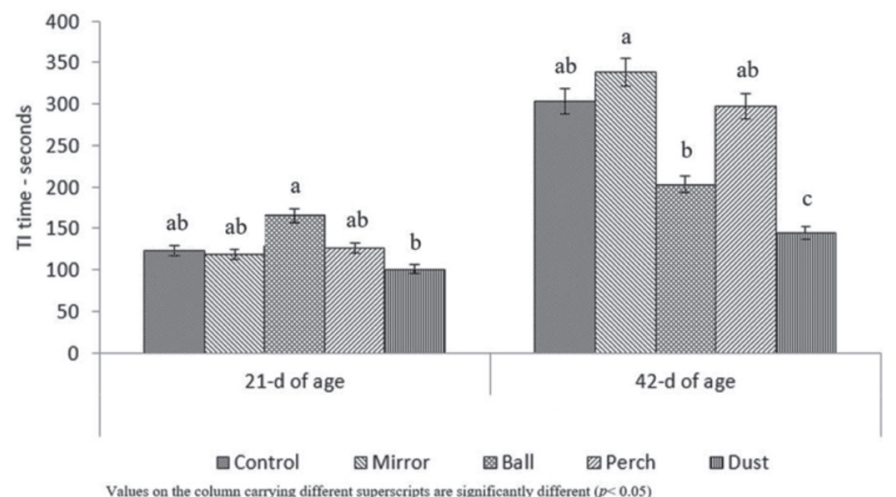

Figure 5 - Tl durations (seconds) in 21-d and 42-d of age.

The perch group had a serious effect on gait score among the EE applications (Fig. 6). The lowest effect was observed in the control groups $(p<0.05)$. Gait scores of the perching group were the lowest while the control group's was the highest. This statement can be explained as follows: bad walk gets high points. So, we can say that EE has improved walking ability.

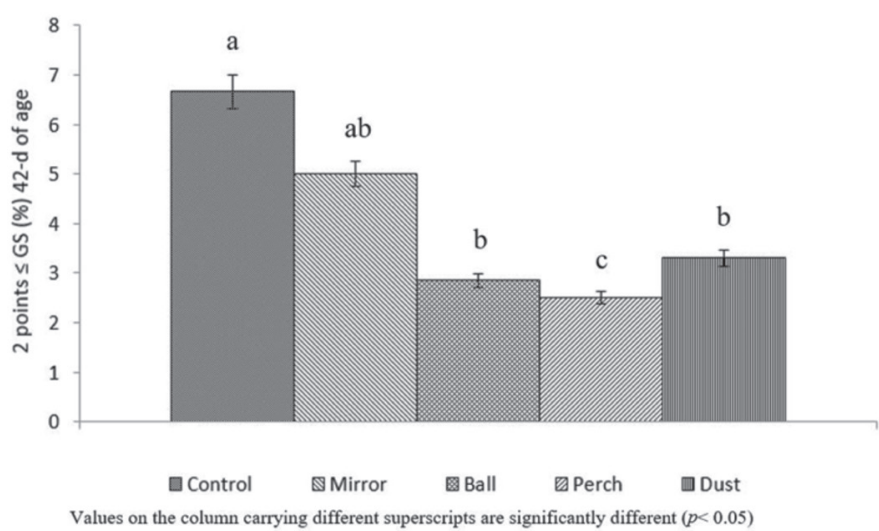

Figure 6 - Two points $\leq$ GS (\%) in 42-d of age.

Blood biochemistry of 42-d-old experimental chicks are presented in Table 2 . The highest cholesterol values were determined for mirror $(2.45 \pm 0.09 \mathrm{mmol} / \mathrm{l})$, perch
$(2.42 \pm 0.11 \mathrm{mmol} / \mathrm{l})$ and ball $(2.34 \pm 0.08 \mathrm{mmol} / \mathrm{l})$ groups respectively. The highest total protein ratio was determined for the dust group $(39.63 \pm 1.27 \mathrm{~g} / \mathrm{l})$ and the lowest for the perch group $(34.15 \pm 1.76 \mathrm{~g} / \mathrm{l})$ $(p<0.05)$. White blood cell value of the control groups $\left(28.23 \pm 0.14 \times 10^{3} / \mathrm{mm}^{3}\right)$ was found higher than the EE groups as a result of hemogram analysis. Ball groups' haematocrit count (\%35.21 $\% 0.99)$ and platelet values $\left(0.19 \pm 0.02 \times 10^{8} / /\right)$ were found lower than those of the other groups $(p<0.05)$.

Simsek et al. (2009) determined body weight of the control group as $2291 \mathrm{~g}$ in their study at the end of the $42^{\text {nd }}$ day. In the same study, body weight of the EE groups was determined as $2231 \mathrm{~g}$ at the end of the $42^{\text {nd }}$ day. Bizeray et al. (2002) determined that EE consisting items such as perch and barrier did not affect body weight averages of the broilers determined in the $3^{\text {rd }}$ and $6^{\text {th }}$ weeks in their study. Diktas et al. (2015) did not find statistically significant differences in terms of organ weights of the broilers which were developed slowly at different growth systems in their study. The present study results were consistent with those of the studies that have shown EE has not significantly affected body, and organ weights for broilers (Seremet, 2007; Simsek et al., 2009; Bizeray et al., 2002). In this study, it was observed that body weights of the treatment groups before slaughtering on the $42^{\text {nd }}$ day were similar to those of the control groups. Being coherent with the present study, it was determined in the previous studies that body weight of broiler chicks was between $2380 \mathrm{~g}$ (Kaynak et al., 2010) and $2356 \mathrm{~g}$ (Seremet, 2007).

Eleroglu et al. (2015) determined rectal temperatures of female and male chicks measured in the sixth week were as $41.7^{\circ} \mathrm{C}$ and $41.8^{\circ} \mathrm{C}$ respectively in their study without showing any difference between sexes. Altan et al. (2000) determined rectal temperature value

Table 2 - Blood biochemistry of experimental chicks at 42-d old.

\begin{tabular}{|c|c|c|c|c|c|}
\hline & Control & Mirror & Ball & Perch & Dust \\
\hline Glucose $(\mathrm{mmol} / \mathrm{l})$ & $12.56 \pm 0.25$ & $13.33 \pm 0.28$ & $14.40 \pm 0.35$ & $13.20 \pm 0.32$ & $14.54 \pm 0.21$ \\
\hline Cholesterol (mmol/l) & $1.90 \pm 0.17^{c}$ & $2.45 \pm 0.09^{a}$ & $2.34 \pm 0.08^{b}$ & $2.42 \pm 0.11^{\mathrm{a}}$ & $1.98 \pm 0.09$ \\
\hline Triglyceride (mmol/l) & $1.09 \pm 0.06$ & $1.06 \pm 0.02$ & $1.10 \pm 0.05$ & $0.93 \pm 0.08$ & $0.97 \pm 0.07$ \\
\hline Total protein $(\mathrm{g} / \mathrm{l})$ & $38.80 \pm 1.20^{b}$ & $37.26 \pm 1.49^{b}$ & $36.66 \pm 1.36^{b}$ & $34.15 \pm 1.76^{c}$ & $39.63 \pm 1.27^{a}$ \\
\hline $\mathrm{RBC}\left(\mathrm{x} 10^{6}\right)$ & $2.71 \pm 0.06$ & $2.92 \pm 0.04$ & $2.64 \pm 0.07$ & $2.81 \pm 0.06$ & $2.95 \pm 0.08$ \\
\hline $\mathrm{Hb}(\mathrm{g} / \mathrm{dl})$ & $14.20 \pm 0.46$ & $15.14 \pm 0.39$ & $13.42 \pm 0.61$ & $14.23 \pm 0.54$ & $14.17 \pm 0.63$ \\
\hline $\mathrm{HCT}(\%)$ & $37.16 \pm 1.09^{a}$ & $38.24 \pm 1.43^{a}$ & $35.21 \pm 0.99^{b}$ & $39.27 \pm 0.86^{a}$ & $38.31 \pm 0.94^{a}$ \\
\hline$M C V(f l)$ & $128.27 \pm 6.17$ & $132.64 \pm 6.35$ & $133.74 \pm 7.28$ & $129.29 \pm 7.36$ & $130.36 \pm 6.49$ \\
\hline $\mathrm{MCHC}(\%)$ & $38.17 \pm 1.83$ & $39.27 \pm 2.30$ & $39.43 \pm 2.62$ & $38.55 \pm 1.96$ & $38.24 \pm 1.43$ \\
\hline $\mathrm{MCH}(\mathrm{pg})$ & $50.10 \pm 3.21$ & $51.00 \pm 3.24$ & $51.40 \pm 3.09$ & $50.20 \pm 3.41$ & $50.30 \pm 2.74$ \\
\hline WBC $\left(\times 10^{3} / \mathrm{mm}^{3}\right)$ & $28.23 \pm 0.14^{a}$ & $25.41 \pm 0.16^{b}$ & $25.36 \pm 0.19^{b}$ & $26.43 \pm 0.14^{b}$ & $26.46 \pm 0.15^{b}$ \\
\hline $\operatorname{PLT}\left(\times 10^{8} / \mathrm{I}\right)$ & $0.29 \pm 0.03^{a}$ & $0.26 \pm 0.02^{\mathrm{a}}$ & $0.19 \pm 0.02^{b}$ & $0.24 \pm 0.04^{a}$ & $0.28 \pm 0.03^{a}$ \\
\hline
\end{tabular}

All values are means \pm SEM. Values in the same row carrying different superscripts are significantly different $(p<0.05)$ 
in control groups in the sixth week as $40.71{ }^{\circ} \mathrm{C}$. In another study, when the room temperature of control birds were maintained at $21^{\circ} \mathrm{C}$ for 8 weeks, the similar rectal temperatures were obtained (Xie et al., 2015). The current findings are in agreement with the mentioned studies.

Wang et al. (2013) found that the broilers with a short $\mathrm{TI}$ time grew faster and reached higher body weights than the broilers with a long TI duration. Liver and breast weights were also affected from $\mathrm{TI}$ duration. However, short TI duration with a high breast weight caused lower liver weight compared to body weight ( $P=0.053)$. The present results were compatible with the study of Turkyilmaz et al. (2011) but were non concordant with the studies of Fidan et al. (2014) and Wang et al. (2013). This may result from the differences of treatment. Sinkalu et al. (2016) found that the highest numbers of induction trial attempt were $2.13 \pm 0.34$ obtained in $12 \mathrm{D}: 12 \mathrm{~L}$ cycle and they were recorded at 13:00 $\mathrm{h}$ when the broiler chickens were 8 weeks old. Their findings are in agreement with the result obtained for the perch group in this study.

Skrbic et al. (2009) determined the gait score value as 0.68, Ravindran et al. (2004) as 1.92, De Jonget al. (2014) as 2.10. The present gait score was higher than the findings of Skrbic et al. (2009) and lower than the findings of others. Alves et al. (2016a) determined the gait score value $(2<\mathrm{GS})$ as $5.2 \%$. The obtained $\mathrm{EE}$ results in the present study were lower than findings. The values of our control group were higher than in their results. This situation may have been caused by the use of rice husks as the litter material in their study. All in all, this methodology will be useful tool to assess how broilers walk (Alves et al., 2016b).

Fidan et al. (2014) determined glucose as 12.81 $\mathrm{mmol} / \mathrm{l}$, cholesterol as $3.02 \mathrm{mmol} / \mathrm{l}$, triglyceride as 1.01 $\mathrm{mmol} / \mathrm{l}$ and total protein as $31.53 \mathrm{~g} / \mathrm{l}$ at the end of their study on broilers. Aslan et al. (2005) determined glucose as $2.07 \mathrm{~g} / \mathrm{L}$ and cholesterol as $1.86 \mathrm{~g} / \mathrm{L}$ in the $4^{\text {th }}$ week while glucose was $2.11 \mathrm{~g} / \mathrm{L}$ and cholesterol was $1.92 \mathrm{~g} / \mathrm{L}$ in the $8^{\text {th }}$ week. Toghyani et al. (2011) found total protein as $3.4 \mathrm{~g} / \mathrm{dl}$, triglyceride as $50 \mathrm{mg} /$ $\mathrm{dl}$, and cholesterol as $156 \mathrm{mg} / \mathrm{dl}$. Pandurang et al. (2011) obtained glucose as $174.17 \mathrm{mg} / \mathrm{dl}$ and total protein values as $6.03 \mathrm{~g} / \mathrm{dl}$. Abdelrahman et al. (2012) determined glucose as $277.3 \mathrm{mg} / \mathrm{dl}$, total protein as $2.50 \mathrm{~g} / \mathrm{dl}$, cholesterol as $224.7 \mathrm{mg} / \mathrm{dl}$ and triglyceride as $129.1 \mathrm{mg} / \mathrm{dl}$. Wang et al. (2013) found that total protein ratio and serum cholesterol ratio were high for treatment group which had perch and sand bath. Turkyilmaz et al. (2011) reported that cholesterol and glucose levels, and total protein ratio of stress raised broilers decreased with the increase of stress. No significant difference was not reported between cholesterol, triglyceride, glucose levels and plasma's total protein content in other studies (Seremet, 2007; Diktas et al., 2015).

Blood biochemistry is affected by several factors, such as season, age, breed, nutrition and stress (Michael et al., 1992; Davis et al., 2000). Although there are limits with reference values in blood, it has been found that the differences occurring in the blood may be caused by factors such as stress of blood collection and applied EE objects may have influenced the activity of animals. This study results were consistent with the findings of Seremet (2007) and Diktas et al. (2015).

Atmaca etal. (2012) determined the values of control group's hemogram analysis result were erythrocyte (RBC) as $2.42 * 10 \% / \mathrm{mm}^{3}$, hemoglobin $(\mathrm{Hb})$ as $11.24 \mathrm{~g} /$ $\mathrm{dl}$, hematocrit (HCT), as $32.43 \%$, Mean Corpuscular Volume (MCV), as 135,61 fL, Mean Corpuscular Hemoglobin $(\mathrm{MCH})$, as $47.6 \mathrm{pg}$, Mean Corpuscular Hemoglobin Concentration (MCHC) as 35.16\%, leucocyte (WBC)as $31.43 * 10^{3} / \mathrm{mm}^{3}$. Fidan et al. (2014) determined $\mathrm{Hb}$ as $8.26 \mathrm{~g} / \mathrm{dl}, \mathrm{HCT}$ as $23.57 \%$ at the result of control group's hemogram analysis. Aslan et

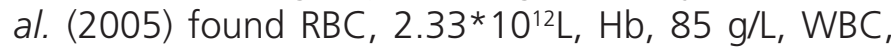
$38,5 * 10 \% / \mathrm{L}, \mathrm{PLT}, 0.23 * 10^{8} / \mathrm{L}$ at the $4^{\text {th }}$ week according to hemogram analysis. They determined values as

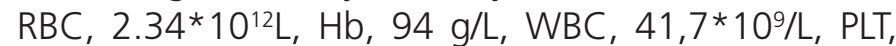
$0.29 * 10^{8} / \mathrm{L}$ at the $8^{\text {th }}$ week of the hemogram analysis result respectively at the same study. Toghyani et al. (2011) determined RBC, 1.97*10\%/L, WBC, 22,8*103/L, $\mathrm{Hb}, 11.4 \mathrm{mg} / \mathrm{ml}, \mathrm{HCT}, \% 25, \mathrm{MCV}, 130 \mathrm{fL}, \mathrm{MCH}, 58 \mathrm{pg}$ and $\mathrm{MCHC}, 44,9 \%$ in their study. Abdelrahman et al. (2012) determined as WBC, 24.81*103/L, RBC, 2.80 *10' $\mathrm{L}, \mathrm{Hb}, 11 \mathrm{~g} / \mathrm{L}, \mathrm{MCV}, 113.21 \mathrm{fL}$ and $\mathrm{MCH}, 34.73 \mathrm{pg}$ in their study on broilers. Current findings was similar to those of Atmaca et al. (2012), Fidan et al. (2014), Aslanet al. (2005) and Toghyani et al.(2011).

Chickens can behave in accordance with their basic needs in the environment that they are grown. Instead of monotone setting, poultry can be stimulated to display their basic behaviors via EE. Thus, animals' welfare level is expected to increase without causing any negative effect on their performances. Taken together, these findings provide important evidence that EE applications does a potentially positive contribution to the welfare of broiler chicks. To conclude, the environmental enrichments (ball, mirror, dust and perch) improve welfare of the birds without affecting the growth performance and lymphoid organ weights. 


\section{ACKNOWLEDGEMENT}

This work, a part of MSc study of Mehmet Yildirim, was supported by the Scientific Research Projects Coordinatorship of Ahi Evran University in Turkey with PYO-ZRT.4003/2.13.007project number.

\section{REFERENCES}

Abdelrahman $\mathrm{AH}$, Kamel HH, Ahmed WM, Mogoda OSH, Mohamed $\mathrm{AH}$. Effect of Bactocell $\circledast$ and revitilyte-plustm as probiotic food supplements on the growth performance, hematological, biochemical parameters and humoral immune response of broiler chickens. World Applied Sciences Journal 2012;18(3):305-316.

Adeniji OB. Effects of environmental enrichment strategies on behavior and production performance of broiler breeder chickens reared at elevated temperatures [thesis]. Knosville (TN): University of Tennessee; 2012.

Almeida Paz ICL, Garcia RG, Bernardi R, Nääs IA, Caldara FR, Freitas LW, et al. Selecting appropriate bedding to reduce locomotion problems in broilers. Brazilian Journal of Poultry Science 2010;12:189-195.

Altan $\mathrm{O}$, Seremet $\mathrm{C}$, Bayraktar $\mathrm{H}$. The effects of early environmental enrichment on performance, fear and physiological responses to acute stress of broiler. Archiv für Geflügelkunde 2013;77(1):23-28.

Altan O, Altan A, Cabuk M, BayraktarH. Effect of heat stress on some blood parameters in broilers. Turkish Journal of Veterinary and Animal Sciences 2000;24:145-148

Alves MCF, Almeida Paz ICL, Nääs IA, Garcia RG, Caldara FR, Baldo GAA, et al. Locomotion of commercial broilers and indigenous chickens. Revista Brasileira de Zootecnia 2016a;45(7):372-379.

Alves MCF, Almeida Paz ICL, Nääs IA, Garcia RG, Caldara FR, Baldo GAA, et al. Equilibrium condition during locomotion and gait in broiler chickens. Revista Brasileira de Ciência Avícola 2016b;18(3):419-426.

Arctander P. Comparative studies of avian DNA by restriction fragment length polymorphism analysis: convenient procedures based on blood samples from live birds. Journal of Ornithology 1988;129:205-216.

Arranz L, De Castro NM, Baeza I, Maté I, Viveros MP, De la Fuente M. Environmental enrichment improves age related immune system impairment: long-term exposure since adulthood increases life span in mice. Rejuvenation Research 2010;13:415-428.

Aslan R, Dundar Y, Eryavuz A, Bulbul A, Kucukkurt I, Fidan AF, et al. Effects of various quantities of yucca schidigera powder (deodorase) added to diets on the performance, some hematological and biochemical blood parameters, and total antioxidant capacity of laying hens. Revue de Médecine Vétérinaire 2005;156(6):350-355.

Atmaca N, Yalcinkaya I, Ozturk H, Yildirim E, Emre B. The effects of mannanoligosaccharide and organic zinc on some electrocardiographic and haematologic parameters in broilers. Atatürk Üniversitesi Veteriner Bilimleri Dergisi 2012;7(3):193-200.

Belz EE, Kennell JS, Czambel RK, Rubin RT, Rhodes ME. Environmental enrichment lowers stress-responsive hormones in singly housed male and female rats. Pharmacology Biochemistry and Behaviour 2003:76(3-4):481-486

Benaroya-Milshtein N, Hollander N, Apter A, Kukulansky T, Raz N, Wilf A. Environmental enrichment in mice decreases anxiety attenuates stress responses and enhances natural killer cell activity. European Journal of Neuroscience 2004;20:1341-1347.
Benoff FH, Siegel PB. Genetic analyses of tonic immobility in young Japanese quail (Coturnix coturnix Japonica). Animal Learning Behaviour 1976:4:160-162.

Bizeray D, Estevez I,Leterrier C,Faure JM.Effects of increasing environmental complexity on the physical activity of broiler chickens. Applied Animal Behaviour Science 2002;79:27-41.

Branch CL, Kozlovsky DY, Pravosudov VV. Elevation related variation in aggressive response to mirror image in mountain chickadees. Behaviour 2015;152(5):667-676

Cockrem JF. Stress, corticosterone responses and avian personalities Journal of Ornithology 2007;148:169-178.

Daneshyar M, Kermanshahi H, Golian A. Changes of biochemical parameters and enzyme activities in broiler chickens with cold-induced ascites. Poultry Science 2009:88:106-110. Doi: 10.3382/ps.200800170.

De Jong IC, Gunnink H,Van Harn J. Wet litter not only induces foot pad dermatitis but also reduces overall welfare, technical performance and carcass yield in broiler chickens. The Journal of Applied Poultry Research 2014;23:51-58

Davis GS, Anderson KE, Carroll AS. The effects of long-term caging and molt of single comb white leghorn hens on herterophil to lymphocyte ratios, corticosterone and thyroid hormones. Poultry Science 2000;79:514518.

Diktas M, Sekeroglu A, Duman M, Yildirim A. Effect of different housing systems on production and blood profile of slow-growing broilers. Kafkas Üniversitesi Veteriner Fakültesi Dergisi 2015;21(4):521-526.

Eleroglu H, Yildirim A, Duman M, Sekeroglu A. The welfare of slow growing broiler genotypes reared in organic system. Emirates Journal of Food and Agriculture 2015;27(5):454-459.

Estevez I. Behaviour and environmental enrichment in broiler breeders. In: Hocking P, editor. Biology of breeding poultry. Wallingford: CABI; 2009. p.261-283.

Fernandes DPB, Silva IJO, Nazareno AC, Donofre AC, Sevegnani KB. Recognition of colors of objects and food opposite chromaticities by broiler chicks. Arquivo Brasileiro de Medicina Veterinária e Zootecnia 2015;67(3):873-881.

Fidan DE, Turkyilmaz KM, Nazligul A, Aypak US, Karaarslan S. The effects of pre slaughter shackling on some stress parameters, fear, and behavioral traits in broilers. Veterinarija Ir Zootechnika 2014;67(89):24-28.

Garriga C, Hunter RR, Amat C, Mitchell MA, Moretti M. Heat stress increases apical glucose transport in the chicken jejunum. American journal of physiology. Regulatory, Integrative and Comparative Physiology 2006;290:195-201

Jiao HC, Jiang YB, Song ZG, Zhao JP, Wang XJ, Lin H. Effect of perch type and stocking density on the behaviour and growth of broilers. Animal Production Science 2014;54(7):930-941.

Jones RB. The tonic immobility reaction of the domestic fowl: A review. World's Poultry Science Journal 1986;42:82-96

Jones RB, Faure JM. Tonic immobility (righting time) in the domestic fowl: effects of various methods of induction. Indian River State College Medicine Science 1980;8:184-185

Jones RB, Carmichael NL, Rayner E. Pecking preferences and pre-dispositions in domestic chicks: Implications for the development of environmental enrichment devices. Applied Animal Behaviour Science 2000;69:291312. 
Kaynak I, Gunes H, Kocak O. Effects of stocking density on broiler performance. Journal of The Faculty of Veterinary Medicine Istanbul University 2010;36(1):9-19.

Kestin SC, Knowles TG, Tinch AE, Gregory NG. Prevalence of leg weakness in broiler chickens and its relationship with genotype. Veterinary Record 1992;131:190-194.

Leone $\mathrm{EH}$, Estevez I. Economic and welfare benefits of environmental enrichment for broiler breeders. Poultry Science 2008;87:14-21.

Meijer MK, Sommer R, Spruijt BM, Van Zutphen LF, Baumans V. Influence of environmental enrichment and handling on the acute stress response in individually housed mice. Laboratory Animals 2007;41:161-173.

Michael CA, Barry O, Hughes AE. Poultry production systems behaviour, management and welfare. Wallingford: Redwood Press; 1992.

NRC - National Research Council. Nutrient requirements of poultry. 9th ed. Washington: National Academy Press; 1994.

Pandurang LT, Kulkarni GB, Gangane GR, More PR, Ravikanth K, Maini S, et al. Overcrowding stress management in broiler chicken with herbal antistressor. Iranian Journal of Applied Animal Science 2011;1(1):4955 .

Ravindran V, Thomas DV. Performance and welfare of broilers as affected by stocking density and in-feed antibiotic supplementation. Proceedings of the $16^{\text {th }}$ Australian Poultry Science Symposium; 2004 Fev 9-11; Sidney, New South Wales. Australian; 2004

Siegel HS. Stress, strains and resistance. British Poultry Science 1995:36:322.

Sinkalu VO, Ayo JO, Abimbola AA, Ibrahim JE. Effects of melatonin on cloacal temperature and erythrocyte osmotic fragility in layer hens during the hot-dry season. Journal of Applied Animal Research 2015;43(1):52-60.

Sinkalu VO, Ayo JO, Adelaiye AB, Hambolu JO. Melatonin modulates tonic immobility and vigilance behavioural responses of broiler chickens to lighting regimens during the hot-dry season. Physiology \& Behavior 2016;165:195-201.
Skrbic Z, Pavlovski Z, Lukic M, Peric L, Milosevic N. The effect of stocking density on certain broiler welfare parameters. Biotechnology in Animal Husbandry 2009:25(1-2):11-22.

Seremet C. Effects of chronic environmental stress on behaviours related with fear and stress physiology in broilers [thesis]. Izmir (TR): Ege University; 2007.

Simsek UG, Dalkilic B, Ciftci M, Cerci IH, Bahsi M. Effects of enriched housing design on broiler performance, welfare, chicken meat composition and serum cholesterol. Acta Veterinaria Brno 2009;78:67-74.

SPSS. Statistical Package for the Social Sciences, ver. 16.0. Chicago: SPSS 2007

Taskin A. Effects of aromatic plants on broiler meat quality and tonic immobility reaction [thesis]. Hatay (TR): Mustafa Kemal University 2009

Toghyani M, Tonghyani M, Gheisari A, Ghalamkari G, Eghbalsaied S. Evaluation of cinnamon and garlic as antibiotic growth promoter substitutions on performance, immune responses, serum biochemical and haematological parameters in broiler chicks. Livestock Science 2011;138:167-173

Turkyılmaz MK, Nazligul A, Pinar ED, Ulutas A. The Effects of Acute Noise on Fear and Some Stress Parameters in Broilers. Kafkas Universitesi Veteriner Fakultesi Dergisi 2011;17(6):957-962

Wang S, Ni Y, Guo F, Fu W, Grossmann R, Zhao R. Effect of corticosterone on growth and welfare of broiler chickens showing long or short tonic immobility. Comparative Biochemistry and Physiology Part A.2013; $164: 537-543$.

Widowski TM, Duncan IJH. Working for a dust bath: Are hens increasing pleasure rather than reducing suffering? Applied Animal Behaviour Science 2000;68:39-53.

Xie J, Tang L, Lu L, Zhang L, Lin X, Liu HC, et al. Effects of acute and chronic heat stress on plasma metabolites, hormones and oxidant status in restrictedly fed broiler breeders. Poultry Science 2015;94:1635-1644. 